\title{
16 The political economy of energy and climate policy in South Africa
}

\author{
Jonathan Hanto, Akira Schroth, Lukas Krawielicki, \\ Pao-Yu Oei, and Jesse Burton
}

\section{Introduction}

The South African coal sector has had a significant impact on South Africa's socio-economic landscape. Interest groups favoring coal have been influential in policy-making processes, especially due to coal's dominant role within the energy sector. As the energy sector is responsible for $80 \%$ of South Africa's greenhouse gas (GHG) emissions (NPC 2018), a transition away from coal is the key for the country to achieve its Nationally Determined Contributions (NDCs) in line with the ratified Paris Agreement, its domestic policy targets and national development goals, and to reduce negative externalities from coal mining and coal power plants such as pollution and negative health effects (Nkambule and Blignaut 2017).

In 2019, coal accounted for about $75 \%$ of total primary energy supply and $88 \%$ of South Africa's electricity generation (Enerdata 2020). It has been a critical part of South Africa's economy for decades and provides domestic inputs for electricity generation (Eskom 2020a). Coal mining contributes $2.3 \%$ to South Africa's GDP with about $40 \%-45 \%$ of the sales income attributable to the export market, namely to India, Pakistan and Southeast Asia (Strambo et al. 2019; Chamber of Mines 2018; IEEFA 2019).

Currently, the prospects of the coal export markets are deteriorating and South Africa is struggling to meet electricity demand with an aging fleet of coal power plants (IEEFA 2019). As costs of renewable energy sources (RES) are decreasing, the sector is expected to further shrink in the years to come (Burton et al. 2018a; IEA 2019; 2020b; Oyewo et al. 2019). Meanwhile, due to high RES potential and a changing policy landscape, a steady increase of Independent Power Producers (IPPs) - mainly active in the RES sector - can be observed (DMRE 2020a; 2020b). With an expected increase in energy demand but a gap in power capacity, the diversification of the energy sector to ensure security of supply has become a primary target on the side of politics and business alike (Eskom 2020b; DMRE 2019; Ndlovu and Inglesi-Lotz 2019).Yet moving away from coal creates challenging issues for the country and the Mpumalanga province in particular. Considering the country's high unemployment rate of over $40 \%$ and the vast inequality represented by a Gini coefficient of 0.63 , now 
exacerbated by the Covid-19 pandemic, the concept of a just transition that acknowledges socio-economic and environmental aspects is regarded as a crucial component for a successful low-carbon transition, including coal phase-out (World Bank 2019; Wright and Calitz 2020b).

The dependency on coal and the multitude of socio-economic challenges have increased focus on the political economy of coal and energy in South Africa. Previous literature identifies several political and economic drivers as the most relevant for the continued dominance of coal. One of these drivers is the "minerals-energy complex", consisting of the mining and energy sectors and related sub-sectors of manufacturing that use their influence for continued mineral profits (Baker et al. 2014, 2015; Trollip 2020). Incumbent actors, like the vertically integrated state-owned utility Eskom, which provides more than $90 \%$ of the national electricity supply, try for many years to maintain a regimefavorable environment through resisting change and creating inertia (Ting and Byrne 2020), as have other large emitters. Consequently, Caprotti et al. (2020) describe South Africa's energy policy and practice landscape as highly complex and dynamic while simultaneously being rigid, inefficient and nontransparent, partly a result of path dependency in apartheid-era institutions and policy (Marquard 2006; Steyn 2001). Nevertheless, changes in regulation and legislation are slowly creating a more RES-favorable policy environment (GreenCape 2020), while a financial crisis at Eskom and shareholder pressure to divest from coal mining and large emitters are causing incumbents to explore pathways away from coal.

Modeling approaches by Oyewo et al. (2019), Hanto et al. (2021), Arndt et al. (2019) and Wright and Calitz (2020a) show that, in any least cost scenarios in line with the $2^{\circ} \mathrm{C}$ global temperature target, no new coal capacities are being built. Moreover, much analysis projects an increased penetration of RES with more ambitious carbon constraints, especially wind and photovoltaics (PV) (McCall et al. 2019; Roff et al. 2020). This leads to a significant increase in employment, albeit much more decentralized jobs are compared to the current, highly concentrated employment in the coal sector.

This chapter provides a theory-guided analysis into the political economy of energy in South Africa to understand the driving societal and political forces behind the ongoing dominance of coal. The analysis is based on 20 in-depth semi-structured expert interviews ${ }^{1}$ with 21 actors associated with the energy and mining sectors in South Africa, which were conducted between August 24, 2020, and December 20, 2020, via Zoom. The interviews were evaluated and coded in accordance with the political economy framework by Jakob et al. (2020) covered in Chapter 1, which assumes that energy and climate policies are the results of a complex interplay between actors with different objectives influenced by contextual factors. Interviews highlighted the diverse group of actors involved in the energy sector and revealed their objectives and means of pursuing their respective interests. The results are then used to examine the multitude of contextual factors influencing decision-making processes. The interview results have been complemented and verified by existing research 
literature, news articles and documents on policies and regulations issued by the government.

The following section outlines relevant background information regarding contextual factors and actors. The "Results" section presents the main objectives in the energy sector. The "Discussion" section discusses the findings and relevant policy implications. The "Conclusion" section concludes.

\section{Energy context and relevant actors}

South Africa's energy sector is still shaped by the country's apartheid history and postapartheid political, social and economic forces (Marquard 2006; Baker et al. 2014). Given South Africa's high coal endowment and historical development of the sector, the fuel was historically a source of cheap electricity for energyintensive growth and in other industries (e.g. coal-to-liquid productions). Coal's key position in South Africa's political economy arose as a result of a combination of factors, including industrial policy oriented toward mining and minerals' beneficiation, strong support by the government through direct and indirect subsidies (Burton et al. 2018b) and national and international investors targeting coal (Baker et al. 2014). The government itself is deeply intertwined with coal interests, given that the state-owned utility Eskom owns most of South Africa's 40-GW coal power fleet, and coal mining has been a key sector for postapartheid economic redistribution, connecting political elites to mining interests. However, Eskom is now a national liability, and in a financial and an operational crisis, it requires ongoing state bailouts to repay otherwise unserviceable debt. In addition, 15 years of load shedding culminated in 2020 for 10\% of the year (Wright and Calitz 2020c). Structural problems on Eskom's end, including cost and time overruns at new coal plants, tariffs that do not reflect underlying generation costs, as well as mismanagement and corruption have left the utility highly indebted and incapable of meeting electricity demand (DPE 2019). As coal is becoming increasingly uneconomical, international diversified miners have divested or de-merged their coal mining businesses and sold assets to local actors (e.g. Anglo American, South 32), while other large mining houses have announced limits on new investments in coal mining (Glencore, Exxaro) (Burton et al. 2018a; IEEFA 2019).

Despite these developments, competing interests that benefit from coal still support the maintenance and growth of the sector. This includes parts of government, who advocate for clean coal, a complex set of coal-related trade unions with sometimes contradictory views on maintaining coal vs creating new jobs, climate policy and just transition issues, and local coal mining companies, their owners and financiers. The national discussion focuses heavily on jobs and the risks to coal-dependent municipalities. Throughout the entire coal value chain, the sector currently employs about 120,000 people $(0.7 \%$ of total national workforce), adding to the notion of coal being key to socio-economic development, especially in highly concentrated coal mining areas (e.g. 
Mpumalanga Province), which has led to strong opposition to RES (Stat S.A. 2021; TIPS 2020).

On the other hand, the idea of a low-carbon transition and the uptake of RES is driven by a new group of actors consisting of pro-renewable parts of government, new investors, especially international IPPs, and civil society, including NGOs and think tanks. While generally a trend toward more RESfriendly policies can be observed, the regulatory environment is still seen as stiff and the slow progression in the implementation of policies and regulations, along with a government hiatus in RES procurement, has been causing uncertainty for investors (GreenCape 2020).

The energy sector in South Africa is predominantly regulated by the government through the Department of Mineral Resources and Energy (DMRE) as the policy and regulatory arm of the state are responsible for electricity generation and allocation of new capacity, as well as mining regulation. The Department of Public Enterprises (DPE) is responsible for Eskom, while the national electricity regulator of South Africa (NERSA) determines the tariffs and charges for Eskom. Additional state ministries shaping the context of energy- and coal-related decisions are the Department of Trade, Industry and Competition (DTIC), which oversees the energy sector from a localization and industrial development perspective, and the Department of Forestry, Fisheries and the Environment (DFFE), which is responsible for environmental concerns and preserving natural resources, including climate change policy (Climate Action Tracker 2020; GreenCape 2020).

Figure 16.1 gives an overview of relevant policies and plans between 2000 and 2020.

The National Development Plan (NDP), the draft Integrated Energy Plan (IEP) and the Renewable Energy White Paper lay the general foundation for a more equal and less carbon-intensive society through sustainable economic growth (National Planning Commission 2012; Department of Energy 2016; Department of Environmental Affairs 2011). The Integrated Resource Plan (IRP) 2019 is the national government's power plan from 2018 until 2030. It foresees a decrease in coal capacities from $38 \mathrm{GW}$ to $33.3 \mathrm{GW}$ and a substantial increase in PV from 1.6 GW to 8.2 GW, wind from 2.5 GW to $17.7 \mathrm{GW}$ and distributed generation from $0.5 \mathrm{GW}$ to $4 \mathrm{GW}$ as well as the introduction of battery storage until 2030 (DMRE 2019).

While the IRP outlines how demand will be supplied, the Renewable Energy Independent Power Producer Procurement Programme (REIPPPP) plays a crucial role in procuring RES through its bidding process that has thus far procured more than $6 \mathrm{GW}$ in four bidding windows. Furthermore, policy tools and laws like the carbon tax, offsetting schemes and the Climate Change Bill specifically target climate change mitigation (GreenCape 2020). However, the carbon tax was implemented in 2019 and set at a low rate, while other policies and regulations are falling behind their initial targets. As Eskom refused to sign power purchase agreements (PPAs), round 4 procurement from the REIPPPP 


\section{$\square$ Coal $\square$ Nuclear $\square$ Hydro $\square$ Oil $\square$ Renewables}

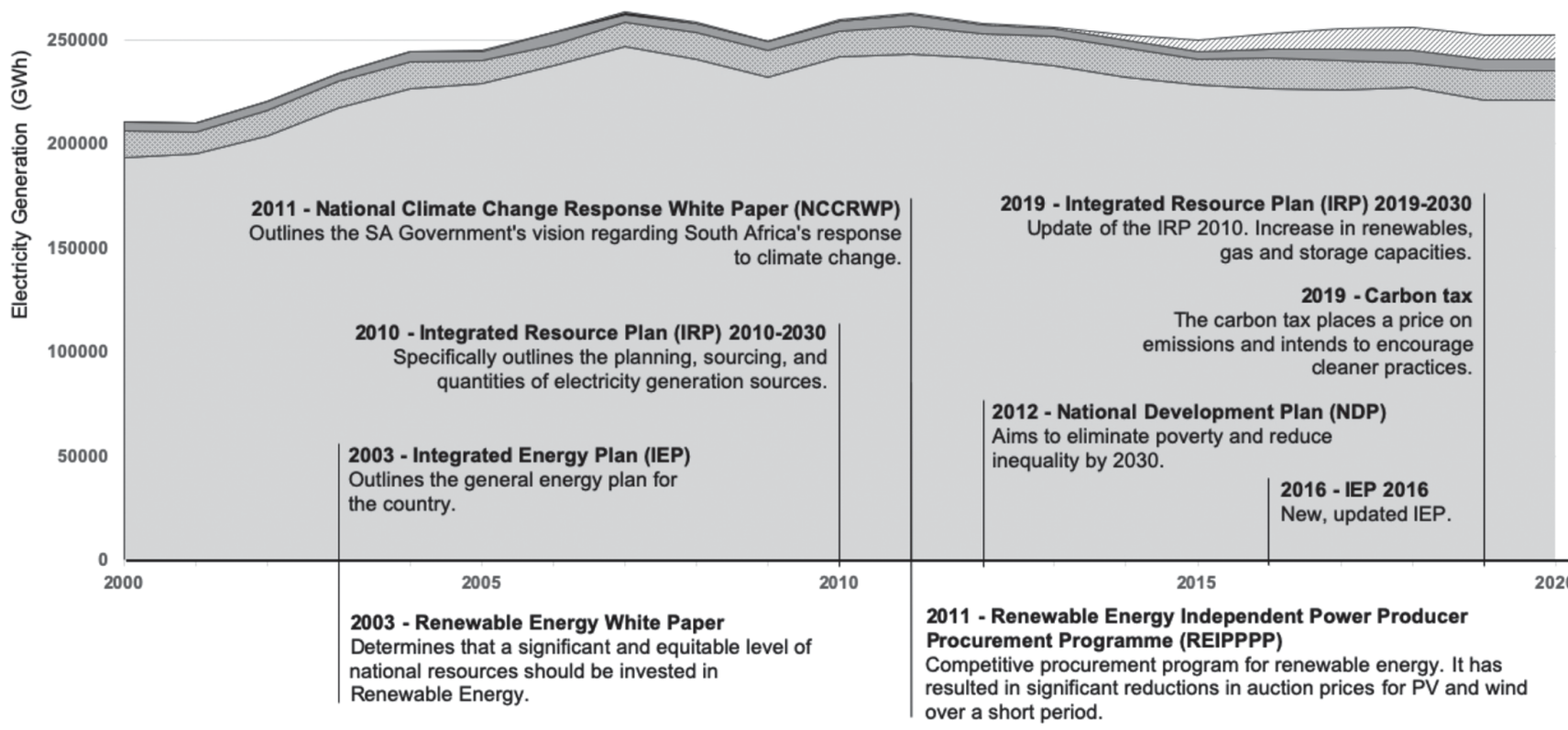

Figure 16.1 Overview of electricity generation (2000-2020) and relevant government decisions.

Source: Own illustration based on GreenCape (2020) and IEA (2020a). 
was delayed for several years, although PPAs were signed in 2018. The fifth bid window was announced in April 2021. Furthermore, the Climate Change Bill is only expected to be finished in late 2021 (Climate Action Tracker 2020). As a result, the share of renewables in the last 20 years has merely increased from $0.14 \%$ to $4.7 \%$, while coal remained the main electricity source with shares of $91.9 \%$ in 2000 and $87.6 \%$ in 2020 (see Figure 16.1).

\section{Results}

Through a qualitative analysis of the 20 interviews with 21 interviewees in conjunction with a literature review, the important actors, objectives and context factors for the South African energy and mining sectors were determined. The interviewees are categorized into political (p), societal (s) and business (b) actors. In total, five political actors, eight societal actors and eight business actors were interviewed. Following the method of qualitative content analysis by Mayring (2000), the identified objectives were coded content-wise and summarized into four overarching objectives with multiple correlating sub-objectives. Thereby, the number of mentions of an objective in the interviews was not taken into account. In addition, objectives and contextual factors included from the interviews do not necessarily reflect the opinion of the interviewees themselves but could reflect other actors mentioned during the conversation.

From the interviews, four main objectives influencing the national energy sector could be derived: "Energy availability", "Maintaining profitability of the coal sector", "Environmental and climate protection" and "Reducing inequality and employment insecurity". The remainder of this section presents and discusses the four main objectives and their underlying sub-objectives as well as the related actors and relevant contextual factors either favoring the role of coal or encouraging an energy transition toward RES. ${ }^{2}$

\section{Energy availability}

South Africa currently experiences a supply-side crisis with the worst year of load shedding on record in 2019 and electricity tariffs significantly increased over the last decade, resulting in negative effects on business and civil society alike (Goliger and McMillan 2018; Ateba et al. 2019).

\section{Security of supply}

To meet its short-term energy demand and set the foundation for long-term adequacy, immediate measures to ensure security of supply are seen as urgent [p1-p5, s1-s3, s5-s7, b1-b8]. Consequently, the DMRE has issued a 2000-MW Risk Mitigation IPP Procurement Programme (REIPPPP), with the objective to fill the current short-term supply gap and alleviate the current electricity supply constraints (DMRE 2020d). The program is expected to have a hybrid mix of RES and gas to reduce overall costs [p3]. To meet capacity demands, 
interviewees further underlined the urgency for a swift implementation of RES procurement through programs like the REIPPPP [p1, p5, s1, s2, s6, b8].

There is general consensus that solving the financial, structural and operational problems of the national electricity public utility Eskom is essential [p1, p2, p4, p5, s1, s2, s4-s8, b1-b8]. Eskom has a history of mismanagement and an underperforming coal power fleet. Its Energy Availability Factor (EAF) has been considerably lower (70\%) than projected in the promulgated IRP 20102030 (86\%), resulting in constrained capacity (DMRE 2019).

Considering the acute gap in capacity (an estimated shortfall of 4-6 GW for 2025) and the expected decommissioning of $12 \mathrm{GW}$ in aging coal capacity until 2030, the diversification of the power sector is seen as a key lever to ensure security of supply and lower electricity costs while simultaneously reducing emissions through low-carbon power generation sources (Wright and Calitz 2020a). Gas is viewed as a potential transition fuel that would account for baseload power with significantly lower emissions [p5, s1, s7, b2-b5, b7]. However, an increase in gas could hinder the uptake of RES and cause an unwanted lockin $[\mathrm{p} 1, \mathrm{~s} 1, \mathrm{~s} 6]$. Regarding nuclear energy, the government is looking into options for new small modular reactors (SMR) (DMRE 2019). Yet, there are no concrete plans due to their high investment costs and opposition from civil society [p1, s2, s6, b1, b2]. Regarding South Africa's future energy supply, interviewees also mentioned hydrogen as a technology with high commercial potential and as an element helping in the energy storage for intermittent electricity from RES [p2, p5, s1, s8, b1, b4-b6]. The expertise around Fischer-Tropsch-derived liquid fuels together with high potential for RES could position South Africa as a "leader" in the global hydrogen market. However, the technology is in an early stage and its commercial viability still has to be ascertained (Ayodele and Munda 2019).

\section{Affordable electricity}

Affordability of electricity is a key component to industrial and economic growth in South Africa, as higher electricity prices negatively affect households, business and especially energy-intensive users (Goliger and McMillan 2018; Khobai et al. 2017).

Interviewees pointed out that Eskom's high debt needs to be addressed as it inhibits the utility from investing in new ventures and translates into rising electricity prices, which is not seen as socially sustainable [p1, p4, p5, s1, s2, s7, s8, b2, b5, b7]. To keep Eskom afloat, electricity prices have significantly been increased from an average USD 0.027 before 2008 to USD 0.09 per kilowatt-hour $(\mathrm{kWh})$ in 2019 and they are expected to further increase from 2020 onward (Edkins et al. 2010; Businesstech 2019). In an attempt to make the energy market competitive again and increase transparency and accountability [b3], the "unbundling" of Eskom into three business units, generation, transmission and distribution, was announced by President Ramaphosa in 2019 (South African Government 2019). However, there is reluctance toward the 
unbundling of Eskom as it might give too much power to the private sector and lead to greater concentration of ownership and higher prices for electricity users [s1].

Additionally, the diversification of the energy sector, as mentioned in the "Security of supply" section, is critical. Due to South Africa's high renewable energy potential and falling levelized costs of electricity for PV and wind, RES have become a cost-effective, low-emission alternative (Jain and Jain 2017; GreenCape 2020).

\section{Electricity access}

Following a nationwide electrification program, the electrification rate in South Africa is above 90\% since 2018 (Essex and de Groot 2019). However, connecting the remaining, mostly remote or informal communities to the grid or utilizing embedded generation remains a technological and political challenge that needs to be addressed [p2, p4, s3, s7, s8, b7], in part due to perceived risks for Eskom and municipal distribution and for low-income users.

The concept of self-generation has gained momentum in South Africa as companies and private households alike have an interest in procuring their own power to reduce dependence on Eskom [p1, p2, p4, s3, s6, b1-b3, b5, b6]. The government only recently started to see and support self-generation as a possibility to alleviate pressure on the grid and the supply side (DMRE 2020c).

\section{Maintaining profitability of the coal sector}

The profitability of coal is a key factor for its dominance and the incentive to sustain its significance within the South African economy and energy sector [p1-p5, s1-s8, b1-b8]. Coal-revenue-related interest groups are seen to influence political decisions in their favor. This is further reinforced by the narrative of coal as a major contributor to economic growth, industrialization and the provider of national employment throughout its value chain [p1-p5, s1-s8, b1-b8].

\section{Revenue from coal}

Coal-related revenues finance actors on different levels throughout its value chain and make vital contributions to the fiscal situation of administrative bodies through royalties and taxes, especially in coal regions [p1, p2, p4, s1, s3, s6-8, b1, b3, b4]. Major corporations and a lobby with strong political influence are associated with the coal sector in South Africa [p1, p5, s1, s2, s6-s8, b1, b3, b4, b7].

South Africa exports about 30\% of its domestic coal production by volume, which makes coal one of the largest, albeit falling contributor to overall revenues in the sector, and an important asset to acquire foreign currencies. Export coal profits are highly dependent on global commodity markets and exchange rates and even large miners have seen falling EBITDA from coal in recent years. 
Future coal demand on the international markets is generally expected to decline. A decline in exports would lead to lower revenues for the coal sector and increase the risk of stranded assets (Strambo et al. 2019; Chamber of Mines 2018; IEEFA 2019).

Such developments motivate current restructuring efforts of local economic actors that have been focusing on coal [s7, s8, b4, b7] and recent activities of transnational coal mining companies, de-merging the coal assets (e.g. Anglo) or selling their South African coal assets (e.g. South 32) (Burton et al. 2018b; IEEFA 2019). The assets are bought by South African companies, often unlisted (e.g. Seriti). In some cases, the viability of these transactions will rely on renegotiated Eskom coal supply agreements and strong exports, while civil society flags issues with the long-term sustainability to spin off assets and the ability to manage rehabilitation and social closure.

Exxaro, another coal major, has, like Glencore, indicated they will not invest in further coal and pivot into new sectors in the long term.

\section{Rent-seeking and vested interests}

Rent extraction from coal-related activities by actors with political and societal influence was mentioned to account for the sector's continued dominant position within the country [p1, s1, s2, s4, s6, b1].

Interviewees indicated the existence of strong links between stakeholders associated with the coal sector and political actors. The former include companies and official lobby groups representing coal sector interests, trade unions related to coal sector employment and individuals with private ties promoting financial and other vested interests [p1, p2, s1-s4, s6, s7, b1, b3-b5, b8]. Ties exist between the long-term ruling party, the African National Congress (ANC) political elites and coal mining and use, including family ties to companies belonging to, for example, former ministers of Energy and the President, investment holding companies with stakes in the coal sector, including ANC-aligned investment companies and the ANC's Chancellor House, and "state capture" by corrupt interests of ANC politicians (Eberhard and Godinho 2018). The long-standing "Tripartite Alliance" between the South African Communist Party (SACP), the Congress of South African Trade Unions (COSATU) and the ANC exemplifies the institutionalization of such connections. Actors connected to the mining and coal sectors have been holding various positions in one or more of the alliance's member parties whereby pro-coal union leaders have been playing important roles in political institutions (Ting and Byrne 2020). Such leadership constellations sometimes promote coal-favoring policies and regulations, among others motivated by vested interests [s1, s2, s4-6, b1].

Furthermore, sociopolitical ties of decision makers and connected underhand personal interests were mentioned as reasons for the past mismanagement and lock-in of coal within Eskom's portfolio for energy generation [s1, s6, b1, b8]. A new "elite" class has been seen using Black Economic Empowerment (BEE) mechanisms, officially meant to contribute to the expansion of economic 
participation of historically disadvantaged individuals, to promote their own vested interests in the coal sector [s4, s6, b3].

\section{Employment and regional development}

The coal sector has been the pillar of South Africa's energy security in the past decades, providing a local fossil fuel as the primary national source of energy and comparably well-paid employment for lower skill levels. Coal has been the key in the economy's development, not only in the mining sector but also playing a part in broader industrialization (Mathu and Chinomona 2013). However, the standing of the coal sector as a contributor to the national energy security and job market was mentioned as likely to change in the future regarding expected long-term tendencies of an overall coal phaseout [p1, p4, s1, s3, b8]. To foster societal opposition against a national coal phase-out, actors profiting from the sector, including unions, have been seen to promote partly inaccurate narratives about alleged socio-economic costs of this process, especially employment loss [p1, s1, s4, b2, b3, b7, b8]. On the other hand, unions were the progenitors of just transition in climate policy and actively sought to understand the risks and opportunities for workers and promote renewable energy, that is state-owned or socially owned. Overall, organized labor does not act or promote positions homogeneously, even within the same unions or federations. Without active implementation of a just transition, their concerns about job losses and "being left behind" are not without merit [s1, s3, b5, b7].

\section{Environmental and climate protection}

South Africa is the world's 14th largest emitter of GHGs (IEA 2020a). There is consensus about the urgent need for a low-carbon transition and a reduction in fossil fuel use and coal mining to mitigate negative environmental, socio-economic and associated harmful consequences for human health [p1-p5, s1-s8, b1-b8].

\section{Climate change mitigation}

With the current global movement to fight climate change, an increasing number of actors in South Africa also commit to taking mitigating actions [p4, s1, s2, s5, s7, b4]. The country has pledged to peak its GHG emissions by 2025, plateau them for a decade, before an absolute decline. The aim to reach net zero by 2050 was also included in its Low-Emission Development Strategy (LEDS) (UNFCCC 2015; 2020). However, coal-related actors argue that climate change mitigation will lead to job losses and fear that exacerbated environmental and climate legislation might constitute disproportionate economic burdens on businesses and customers. Thus, they call for sensible alignment, implementation and offsetting mechanisms [p1-p4, b3, b4, b5, b8]. Nonetheless, 
some powerful actors such as Sasol are planning to take measures to reduce their emissions [b4-b7].

South Africa's National Climate Change Bill aims for the country to transition toward a lower carbon economy and a climate-resilient society. This is also important to attract international companies, since most of them pay attention to their carbon footprint. Additionally, regulatory instruments like the carbon tax, pollution abatement requirements and the carbon budgets system are supposed to cut GHG emissions and increase pressure on carbon emitters but are currently regarded as ineffective and nonbinding [p3, p4, s1, b4, b5]. The carbon tax in its initial phase (2019-2022) only applies to direct emissions and sets total tax-free allowances as high as $95 \%$. As a result, actors from the government in support of climate change mitigation, NGOs and researchers are calling for more ambitious targets within legislation, which address RES procurement and climate change mitigation (e.g. IRP 2019 and second phase [2023-2030] of the carbon tax) [p1, p4, p5, s1, s3, s5-s8, b4-b6, b8].

Actors from the coal sector are seen to stress alleged possibilities of "clean coal" and carbon capture and storage (CCS) technologies to mitigate the sector's GHG emissions [p2, s1, b3, b5]. However, these technologies are still not economically viable and are seen as a strategy from the coal sector to create inertia (Viebahn et al. 2015).

\section{Procurement of renewables}

To reduce the country's carbon footprint, higher penetration of RES and a regulatory environment favoring their uptake are needed. As Eskom's financial situation prevents internal investments into RES expansions, IPPs and the REIPPPP play an important role in addressing the current capacity gap [p1-p5, s1-s3, s6-s8, b1-b8].

Despite recent changes in legislation to allow for an easier procurement of RES for private investors and municipalities, the procurement process is still seen as "too prescriptive" and "disincentivising" (DMRE 2020c). In a context in which the buildup of new capacities is urgently needed, this hurdle points out the lack of policy certainty in the energy sector [p2, p3, p5, s7, b2-b6, b8]. Moreover, criteria for investors should be aligned with tariffs and consistent with regulatory frameworks to allow the entry of new investors [p2, b3, b5-b7].

Another way to increase investments in large-scale RES is the idea of international concessionary finance based on accelerated retirement of coal-fired power plants, which is expected to simultaneously tackle Eskom's debt issues and reduce the carbon footprint with the support of international funders [s1, s2, s7, s8].

\section{Reducing negative effects from coal}

The continuous use of coal and fossil fuels has led to negative effects on health due to direct or indirect exposure, such as cancer, respiratory and 
cardiovascular problems, and negative environmental and socio-economic effects, such as polluted air, soil and water. Coal mining further increases the risk of water scarcity, a problem expected to worsen in the years to come (Olufemi et al. 2018).

Civil society, despite its limited means, plays an important role in challenging the status quo. Strong activism from communities and civil society organizations, backed by legal action, has challenged pollution issues stemming from mining, coal-fired power stations and refineries [p1, s2, b6]. Campaigns by multiple organizations (e.g. Earthlife Africa, groundWork) successfully challenged new coal plants (e.g. Thabametsi) on the grounds of their potential harm to the environment and human health. Also, new coal mines were stopped on the grounds of their expected detrimental effects on the environment, climate and society (e.g. Mabola Protected Environment in Mpumalanga Province) (Humby 2018; Reuters 2019).

\section{Reducing inequality and employment insecurity}

The triple challenges of poverty, inequality and unemployment are relevant when assessing the implications of a low-carbon transition in South Africa [p1p4, s1, s6-s8, b1-b8]. Especially the consequences for affected communities and workers must be addressed (Winkler et al.2020). The idea of a just transition has been embedded in climate policy since 2011, as well as in the country's NDCs. It ought to function as a framework to prevent and balance out the loss of employment connected to the coal sector, create local ownership and include all relevant actors [p1, p2, p4, p5, s1-s4, s6-s8, b1-b8].

\section{Creating employment alternatives}

A low-carbon transition entails a reduction in employment in the coal value chain, although the timing of closures and the age, skills and health of workers will be important factors. Considering the already high national unemployment, it is vital to diversify economies and create employment opportunities in affected regions, especially in the Mpumalanga province, where $80 \%$ of coal extraction is concentrated (Spencer et al. 2018; TIPS 2020). An unplanned, opaque and hasty exit from coal might lead to severe negative socio-economic impacts in affected regions and therefore spark social unrest and increased opposition to a low-carbon transition [s2, s3, b5]. As such, the formation of local value chains connected to RES technologies is important to create new local employment opportunities. While general production costs could not compete internationally, some aspects of the production value chain for key components needed for RES, such as cable ties or module assembly, could be localized in South Africa [p5, s1, s4, b1, b2, b4]. Furthermore, the repurposing of old coalfired power plants to natural gas or RES is an option to create employment in affected areas [b5, b7] and is being explored by Eskom's just energy transition project office. 


\section{Jonathan Hanto et al.}

While there is potential for employment in RES, lower salaries and benefits as well as spatial differences between new employment in RES and current employment in coal-mining areas are a problem. Additionally, reskilling is an issue as coal-related jobs are often low-skilled, making it challenging to find fitting jobs with equal pay [p1, p2, s3], partly because of very low wages across the broader economy (Burton et al. 2018a).

These factors play into the hands of pro-coal actors as they call for a slow transition process to cushion the effects of unemployment caused by a declining coal sector and ensure adequate considerations of socio-economic aspects, allowing the transition to be "just". However, regional policymakers already recognize the risks related to coal extraction and use, and the need for a just transition [s1, s3, b5, b7].

\section{Ownership}

The increase of RES through IPPs is generally perceived as beneficial for energy security [p1, p2, p4, s1, s6-s8, b3, b4, b6]. Since these are predominantly owned by foreign companies and private investors, some actors - especially unions - see the trend of privatization of the sector as problematic [s2, s3, s7, b1]. Through public ownership or ownership models, such as communityowned or socially owned capacities, the benefits of RES could go beyond the economic and environmental impacts and include socio-economic aspects of a just transition [p1, p2, p4, s1-s3, s7, b6, b7]. While increasing the number of community-owned energy systems is deemed beneficial, little-to-no communities have the financial capabilities to develop and use them. This situation is seen to highlight the need for new investment schemes [s2, s3, b1].

Though BEE regulations are seen by certain actors as being used to promote vested interests within the coal sector and hamper the expansion of emerging sectors crucial for a coal phase-out [s4, s6, b4, b6], BEE is seen as an essential social justice tool a just transition would have to embrace $[\mathrm{s} 6, \mathrm{~b} 1, \mathrm{~b} 2, \mathrm{~b} 4, \mathrm{~b} 6]$.

\section{Stakeholder engagement}

In line with the concept of a just transition, the focus is increasingly on the involvement of all actors affected by the transition. Therefore, dialogue is initiated on a local, municipal, provincial and governmental level, internationally, and by major national companies like Sasol and Eskom setting up working groups [p1, p2, p4, p5, s1-s3, s6, s8, b1, b2, b4, b5, b7]. The newly created Presidential Coordinating Commission on Climate Change (PCCCC) is regarded as a first step to support the just transition to go about in a coordinated, comprehensive and strategic manner through high-level government leadership (DEFF 2020).

\section{Discussion}

The analysis of the interviews shows that the South African energy sector is currently in an intricate state of high dependency on coal backed by powerful 
actors, on the one hand, and facing a growing demand for alternatives to an increasingly economically, environmentally and socially unviable system, on the other hand. Exacerbated by problems such as the inability to meet national energy demand and the high debt of the main electricity generator Eskom, efforts to transition toward a more diversified, low-carbon energy sector have manifested over the past years.

Nevertheless, the extraction of rents creates an incentive to maintain the current power structures and dependency on coal, resulting in resistance toward new government regulations, policies and the low-carbon transition. Thus, the coal sector is expected to continue constituting an important source of national- and community-level income and provide a significant amount of national employment throughout the near future.

While the government has taken steps to facilitate a competitive and investor-friendly regulatory environment for RES, there are still critical issues related to policy and regulatory certainty. Interviewees described the existing legislative body and state interventions as inconsistent. It is essential that laws and regulations are implemented by means of programs that are securely funded and well managed. To back the uptake of RES and diversification of the energy sector, a more coordinated political effort to allow the implementation of largescale, small-scale and embedded generation through uncomplicated bureaucratic processes and financial incentives is needed.

Ecological fiscal policy tools like the carbon tax present promising first steps. They ought to be part of an effective overarching national strategy for GHG reduction that includes reasonable mechanisms to not disproportionately penalize affected actors but nudge them toward a low-carbon transition.

The issue of unemployment adds another layer of complexity to the discourse of a low-carbon transition in South Africa. To ensure support for a transition from a majority of societal stakeholders, including trade unions and actors in regions that have been relying on coal sector revenues, conscientious planning for finding alternatives to coal-related employment is crucial. Efforts to support the processes need to be intensified throughout several levels of society, business and government. Therefore, local value should be increased through apt ownership schemes and large-scale utility IPP projects ought to increase their focus on social impacts.

\section{Conclusion}

For this research, expert interviews with societal, political and business protagonists associated with the energy and mining sectors in South Africa were analyzed in accordance with the political economy framework by Jakob et al. (2020). Four main objectives influencing the national energy sector were identified: "Energy availability", "Maintaining profitability of the coal sector", "Environmental and climate protection" and "Reducing inequalities and employment insecurity".

The high endowment and dependence on coal, as well as pressing social issues, which are intensified by the Covid-19 pandemic, such as severe social 


\section{Jonathan Hanto et al.}

inequality and high national unemployment rates, lead to a complex and multilayered political and social situation. Climate change mitigation goals and solutions cannot exclusively be considered in the context of low carbon and energy efficiency. Rather, they are tied to broader socio-economic implications. Therefore, they need to be embedded into a just transition framework for South Africa.

Nonetheless, the transition is slowly progressing, given the pressing need for climate change mitigation action and the context of quickly sinking RES installation costs, currently to lower levels than those for coal power generation technologies. But it remains to be seen how quickly coal will be phased out. Further analysis of the complex interplay between different actors associated with the coal and energy sectors, respective objectives and surrounding contextual factors is needed to contest the status quo. A more comprehensive and detailed understanding of the political economy of coal in South Africa would help to effectively establish a transparent regulatory environment and advance a national vision of a socio-economically "just" low-carbon transition.

\section{Grants}

This work has been supported by the German Ministry of Education and Research (BMBF) under the grant number 01LN1704A (CoalExit).

\section{Acknowledgments}

We would like to thank all interviewees for their valuable contributions and insights to this study, as well as Christian Hauenstein, Felipe Corral-Montoya, Paola Yanguas-Parra, Paula Walk, and Nora Stognief from the CoalExit research group for helpful comments and discussions. We would also like to gratefully acknowledge the support of the CoalExit research project (grant number "01LN1704A" funded by the German Ministry for Education and Research) and the Transnational Centre for Just Transitions in Energy, Climate and Sustainability (TRAJECTS).

\section{Appendix}

This chapter contains supplementary online material at https://www.mccberlin.net/pecoal/ch16.

\section{Notes}

1 See Appendix A.1 for the full list of interviewees and A.2 for the full questionnaire.

2 See Appendix A.3 for an overview of relevant objectives, actors and contextual factors identified by the interviewees. 


\section{References}

Arndt, C., Arent, D., Hartley, F., Merven, B., \& Mondal, A. H. (2019). Faster than you think: Renewable energy and developing countries. Annual Review of Resource Economics, 11(1), 149-168. doi:10.1146/annurev-resource-100518-093759

Ateba, B. B., Prinsloo, J. J., \& Gawlik, R. (2019). The significance of electricity supply sustainability to industrial growth in South Africa. Energy Reports, 5(November), 1324-1338. doi:10.1016/j.egyr.2019.09.041

Ayodele, T. R., \& Munda, J. L. (2019). The potential role of green hydrogen production in the South Africa energy mix. Journal of Renewable and Sustainable Energy, 11(4). doi:10.1063/1.5089958

Baker, L., Burton, J., Trollip, H., \& Godinho, C. (2015). The Political Economy of Decarbonisation: Exploring the Dynamics of South Africa's Electricity Sector. doi:10.13140/ RG.2.1.4064.9040

Baker, L., Newell, P., \& Phillips, J. (2014). The political economy of energy transitions: The case of South Africa. New Political Economy, 19(6), 791-818. doi:10.1080/13563467.2013.849674

Burton, J., Caetano, T., \& McCall, B. (2018a). Understanding the Implications of a 2oCCompatible Coal Phase-Out Plan for South Africa. Energy Research Centre, University of Cape Town. Retrieved from www.iddri.org/en/publications-and-events/report/ coal-transitions-south-africa

Burton, J., Lott, T., \& Rennkamp, B. (2018b). Sustaining carbon lock-in: Fossil fuel subsidies in South Africa. In J. Skovgaard \& H. van Asselt (Eds.), The Politics of Fossil Fuel Subsidies and Their Reform (pp. 229-245). Cambridge: Cambridge University Press. doi:10.1017/9781108241946.015

Businesstech. (2019). South Africa's Petrol and Electricity Prices vs the World. Retrieved from https://businesstech.co.za/news/energy/306592/south-africas-petrol-and-electric ity-prices-vs-the-world/, 2019

Caprotti, F., Essex, S., Phillips, J., de Groot, J., \& Baker, L. (2020). Scales of governance:Translating multiscalar transitional pathways in South Africa's energy landscape, Energy Research \& Social Science, 70. https://doi.org/10.1016/j.erss.2020.101700.

Chamber of Mines.(2018). National Coal Strategy for SouthAfrica 2018.Retrieved from www. mineralscouncil.org.za/special-features/604-national-coal-strategy-for-south-africa

Climate Action Tracker (CAT). (2020). Climate Governance-Assessment of the Government's Ability and Readiness to Transform South Africa into a Zero Emissions Society. CAT Climate Governance Series. The Climate Action Tracker. Retrieved from https://climateactiontracker.org/publications/climate-governance-in-south-africa/

DEFF. (2020). Cabinet Approves Climate Change, Emissions Reduction and Waste Management Plans. Department of Environmental Affairs. Retrieved from www.environment.gov. $\mathrm{za} /$ mediarelease/climatechange_emissionsreduction_wastemanagementplans

Department of Energy. (2016). Integrated Energy Plan (IEP). South Africa: Department of Energy - South Africa. Retrieved from www.energy.gov.za/files/iep_frame.html

Department of Environmental Affairs. (2011). National Climate Change Response White Paper. Retrieved from www.gov.za/documents/national-climate-changeresponse-white-paper

DMRE. (2019). Integrated resource plan (IRP2019). Government Gazette. South Africa: Department of Mineral Resources \& Energy. Retrieved from www.energy. gov.za/IRP/irp-2019.html 
(2020a). Key Messages from the Risk Mitigation Independent Power Producer Procurement Programme (RMIPPPP) Bidders Conference, Held on 25 September 2020. Retrieved from www.dmr.gov.za/news-room/post/1870/key-messages-from-therisk-mitigation-independent-power-producer-procurement-programme-rmippppbidders-conference-held-on-25-september-2020, 2020.

. (2020b). Minister MANTASHE Welcomes NERSA Concurrence to Ministerial Determination for the Procurement of $11813 \mathrm{MW}$ of Power. Retrieved from www. energy.gov.za/files/media/pr/2020/Minister-welcomes-Nersa-concurrence-toMinisterial-Determination-for-Procurement.pdf

- (2020c). Licensing exemption notice: Schedule 2 of electricity regulation act 2006. Government Gazette. South Africa: Department of Mineral Resources \& Energy. Retrieved from https://cer.org.za/virtual-library/whats-new/amendmentto-schedule-2-of-the-electricity-regulation-act-4-of-2006

- (2020d). Overview of the Request for Qualification and Proposals for New Generation Capacity under the Risk Mitigation IPP Procurement Programme. South Africa:Department of Mineral Resources \& Energy. Retrieved from www.ipp-rm.co.za/

Department of Public Enterprises (DPE) (2019). Annual Report 2018/2019 Financial Year. Department of Public Enterprises, Republic of South Africa.

Eberhard, A. and C. Godinho (2018). Decarbonization and power market reform in developing countries: the case of South Africa, Oxford Energy Forum, 114, 54-57.

Edkins, M., Marquard, A., \& Winkler, H. (2010). The Effectiveness of National Solar and Wind Energy Policies in South Africa. Energy Research Centre, University of Cape Town.

Enerdata. (2020). Global Energy and $\mathrm{CO}_{2}$ Data. France: Grenoble. Retrieved from www. enerdata.net/research/energy-market-data-co2-emissions-database.htm

Eskom. (2020a). Tariff History. Retrieved from www.eskom.co.za/CustomerCare/ TariffsAndCharges/Pages/Tariff_History.aspx

- (2020b). Medium-Term System Adequacy Outlook 2020. South Africa: Eskom. Retrieved from www.eskom.co.za/Whatweredoing/SupplyStatus/Pages/ SupplyStatusT.aspx

Essex, S., \& de Groot, J. (2019). Understanding energy transitions: The changing versions of the modern infrastructure ideal and the "energy underclass" in South Africa, 1860-2019. Energy Policy, 133(October). doi:10.1016/j.enpol.2019.110937

Goliger,A., \& McMillan, L. (2018). The Tipping Point:The Impact of Rising Electricity Tariffs on Large Firms in South Africa [Working Paper, 2018]/32 [WIDER Working Paper]. doi:10.35188/UNU-WIDER/2018/474-2

GreenCape. (2020). Utility-Scale Renewable Energy -2020 Market Intelligence Report. South Africa: GreenCape. Retrieved from www.greencape.co.za/marketintelligence/

Hanto, J., Krawielicki, L., Krumm, A., Moskalenko, N., Löffler, K., Hauen-stein, C., \& Oei, P.-Y. (2021). Effects of Decarbonization on the Energy System and Related Employment Effects in South Africa. Environmental Science \& Policy, 124 (October): 73-84. https://doi.org/10.1016/j.envsci.2021.06.001.

Humby, T.-L. (2018). The Thabametsi case: Case no 65662/16 Earthlife Africa Johannesburg v minister of environmental affairs. Journal of Environmental Law, 30(1), 145-155. doi:10.1093/jel/eqy007

IEA. (2019). Coal. International Energy Agency. Retrieved from www.iea.org/fuelsand-technologies/coal 
. (2020a). South Africa. International Energy Agency. Retrieved from www.iea. org/countries/south-africa

- (2020b). World Energy Model. International Energy Agency. Retrieved from www.iea.org/reports/world-energy-model

IEEFA. (2019). South African Coal Exports Outlook-Approaching Long-Term Decline. Institute for Energy Economics and Financial Analysis (IEEFA). Retrieved from https://ieefa.org/wp-content/uploads/2019/09/South_Africa_Coal_Exports_ Outlook_Sept-2019.pdf

Jain, S., \& Jain, P. K. (2017). The rise of renewable energy implementation in South Africa. Energy Procedia, 143(December), 721-726. doi:10.1016/j.egypro. 2017.12.752

Jakob, M., Flachsland, C., Steckel, J. C., \& Urpelainen, J. (2020). The Political Economy of Climate and Energy Policy: A Theoretical Framework. Retrieved from https://ecpr.eu/ Events/Event/PaperDetails/45895

Khobai, H., Mugano, G., \& le Roux, P. (2017). The impact of electricity price on economic growth in South Africa. International Journal of Energy Economics and Policy, 7(March), 108-116.

Marquard,A. (2006). The Origins and Development of South African Energy Policy. University of Cape Town. Retrieved from https://open.uct.ac.za/handle/11427/4963

Mathu, K., \& Chinomona, R. (2013). South African coal mining industry: Socio-economic attributes. Mediterranean Journal of Social Sciences, 4(November), 337-357. doi:10.5901/mjss.2013.v4n14p347

Mayring, P. (2000). Qualitative Content Analysis. Forum Qualitative Sozialforschung. Forum: Qualitative Social Research. Retrieved from http://qualitative-research.net/ Fqs/Fqs-e/2-00inhalt-e.Htm, 1(June).

McCall, B., Burton, J., Marquard, A., Hartley, F., Ahjum, F., Ireland, G., \& Merven, B. (2019). Least-cost integrated resource planning and cost-optimal climate change mitigation policy: Alternatives for the South African electricity system. Energy Research Center, SA-TIED WORKING PAPER \# 29.

National Planning Commission. (2012). National Development Plan 2030: Our FutureMake It Work. South Africa: Government of South Africa. Retrieved from www.gov. $\mathrm{za} /$ issues/national-development-plan-2030

Ndlovu, V., \& Inglesi-Lotz, R. (2019). Positioning South Africa's energy supply mix internationally: Comparative and policy review analysis. Journal of Energy in Southern Africa, 30(2), 14-27. doi:10.17159/2413-3051/2019/v30i2a5409

Nkambule, N.P., \& Blignaut,J. N. (2017). Externality costs of the coal-fuel cycle:The case of Kusile power station. South African Journal of Science, 113(9/10), 1-9. doi:10.17159/ sajs.2017/20160314

NPC. (2018). Energy. NPC Economy Series. South Africa: National Planning Commission. Retrieved from www.gov.za/sites/default/files/gcis_document/201802/npcenergy-paper.pdf

Olufemi, A. C., Bello, P. O., \& Mji, A. (2018). Conflict implications of coal mining and environmental pollution in South Africa: Lessons from Niger Delta, Nigeria. African Journal on Conflict Resolution, 18(1), 7-35. doi:10.4314/ajcr.v18i1

Oyewo, A. S., Aghahosseini, A., Ram, M., Lohrmann, A., \& Breyer, C. (2019). Pathway towards achieving 100\% renewable electricity by 2050 for South Africa. Solar Energy, 191(October), 549-565. doi:10.1016/j.solener.2019.09.039 
Reuters. (2019). South African Government Sued Over Coal and Industrial Air Pollution. Reuters. Retrieved from www.reuters.com/article/us-safrica-coalidUSKCN1TB1Q7

Roff, A., Steyn, G., Tyler, E., Renaud, C., Brand, R., \& Burton, J. (2020). A vital ambition: Determining the cost of additional $\mathrm{CO}_{2}$ mitigation in the South African electricity system. Meridian Economics. Retrieved from https://meridianeconomics. co.za/documents/

South African Government. (2019). President Cyril Ramaphosa: 2019 State of the Nation Address | South African Government. Retrieved from www.gov.za/speeches/presidentcyril-ramaphosa-2019-state-nation-address-7-feb-2019-0000\#, 2019.

Spencer, T., Colombier, M., Sartor, O., Garg, A., Tiwari, V., Burton, J., ..., Wiseman, J. (2018). The $1.5^{\circ} \mathrm{C}$ target and coal sector transition: At the limits of societal feasibility. Climate Policy, 18(3), 335-351. doi:10.1080/14693062.2017.1386540

Stat, S. A. (2021). Statistics South Africa. South Africa: Department: Statistics South Africa. Quarterly Labour Force Survey Quarter 4. Retrieved from www.statssa.gov.za/ publications/P0211/P02114thQuarter2020.pdf, 2020.

Steyn, M. E. (2001). Whiteness Just Isn't What It Used to Be:White Identity In a Changing South Africa. Albany: State University Press of New York.

Strambo, C., Burton, J., \& Atteridge, A. (2019). The End of Coal? Planning a Just Transition' in South Africa [SEI Report]. Stockholm: Stockholm Environment Institute. Retrieved from www.sei.org/wp-content/uploads/2019/02/planning-ajust-transition-in-south-africa.pdf

Ting, M. B., \& Byrne, R. (2020). Eskom and the rise of renewables: Regime-resistance, crisis and the strategy of incumbency in South Africa's electricity system. Energy Research and Social Science, 60. doi:10.1016/j.erss.2019.101333

TIPS. (2020). Sector Jobs Resilience Plan: Coal Value Chain. South Africa. Retrieved from www.westerncape.gov.za/110green/files/atoms/files/Final\%20Sector\%20Jobs\%20 Resilience\%20Plans\%20for\%20Coal\%20Value\%20Chain\%202020_0.pdf

Trollip, H. (2020). The politics of energy transitions policy in South Africa. In COP21: Results and Implications for Pathways and Policies for Low Emissions European Societies. COP21 Ripples. Retrieved from www.cop21ripples.eu/

UNFCCC. (2015). South Africa's Intended Nationally Determined Contribution (INDC). Retrieved from www4.unfccc.int/sites/submissions/INDC/Submission\%20Pages/ submissions.aspx

- (2020). South Africa's Low Emission Development Strategy. Retrieved from https:// unfccc.int/documents/253724

Viebahn, P., Vallentin, D., \& Höller, S. (2015). Integrated assessment of carbon capture and storage (CCS) in South Africa's power sector. Energies, 8(12), 14380-14406. doi:10.3390/en81212432

Winkler, H., Keen, S., \& Marquard, A. (2020). Climate Finance to Transform Energy Infrastructure as Part of a Just Transition in South Africa. South Africa. doi:10.13140/ RG.2.2.20414.92482

World Bank. (2019). The World Bank in South Africa. Retrieved from www.worldbank. org/en/country/southafrica/overview

Wright, J. G., \& Calitz, J. R. (2020a). Setting up for the 2020s: Addressing South Africa's Electricity Crises and Getting Ready for the next decade. version 1.1,'January. Retrieved from https://researchspace.csir.co.za/dspace/handle/10204/11282 
(2020b). Setting up for the 2020s: Addressing South Africa's Electricity Crisis and Getting Ready for the next decade ... and Now Covid-19. Presented at the GreenCape and CSIR Webinar. Retrieved from www.researchgate.net/publication/343670969_ Setting_up_for_the_2020s_Addressing_South_Africa.s_electricity_crisis_and_getting_ ready_for_the_next_decade_and_now_Covid-19

(2020c). Load Shedding Over the Next Three Years: Magnitude and Mitigation. Retrieved from www.researchgate.net/publication/345672158_Load_shedding over_the_next_three_years_Magnitude_and_mitigation. In. Pretoria. 